\title{
Between Land and Sea: Reshaping the Belgian Coastline A Case Study between Ostend and Blankenberge
}

\author{
Wim Wambecq, Bruno De Meulder
}

\begin{abstract}
Over time, the Belgian coast has developed into a hardengineered straight defence line - from the sea inwards - of flat beaches, dykes and a storm wall that is reaching its capacity limits. New plans are being developed in some parts of the coast aiming to raise the storm walls up to "acceptable" levels, based on climate change and sea level rise predictions. This follows the trends of raising river protection walls, but continuously insists on the linear urban structure of the coastline: beaches, dyke, urbanization wall on the dunes and housing proliferation into the back polders. These are often low-quality holiday houses built for the summer season rush. This essay investigates an alternative future for the Belgian coast through research-by-design. The design exploration proposes to seize the opportunity of the increased peril, predicted from climate change and subsequent sea level rise. Furthermore, it proposes a shift from hard to soft engineering and a dynamic tidal landscape within which the tourism economy is reinvented.
\end{abstract}

Keywords: estuarine urbanism, forest urbanism, holiday house, landscape urbanism, research-by-design

Urbanization on the Belgian coast is peculiar. It is the result of stupefaction, awe and amazement for the coastal forces, undone by the human hubris. The human presence has been persistent, yet all man-made interventions unleashed on the rebound reactions of natural forces. The roughness of the coastal landscape triggered the development of innovative systems that deal with forces that were once considered uncontrollable. Gradually, 
the coastal landscape was kept under control and through this process of domestication, its natural character vanished. What was once a tidal landscape of continuously moving dunes, intruding and retracting water landscapes and meandering creeks turned into a linear system of sea and a stretch of sand, held by the urbanized dyke. Nowadays, even the polders, another result of the domestication of the sea, are invaded by the holiday driven urbanization.

The post-war leisure economy has played a significant role in the demise of the coastal landscape. The holiday pressure along the $60 \mathrm{~km}$ [37 mi.] long shoreline drastically altered the dynamic natural system and landscape quality. The recreational usage turned nature from a producer of space into an object of consumption. In the summer, the coast fills up with tourists; in the winter, policy makers attempt to fill its emptiness with indoor programs of all kinds. Regardless of the time of the year, the territory is completely adjusted for leisure purposes. In response to this, attempts are being made to safeguard the remaining landscape, which subconsciously guides the coastal landscape into an even more static condition.

There is an extensive body of knowledge that can form the basis of future design research in the field of climate change adaptation on the Belgian coast, and that shows how urban form can coexist with these future models. Various studies tackle the coastline's future, such as "The Future Commons 2070" (Vlaams Architectuurinstituut et al. 2011; Janssens and Geldof 2014, Cornilly 2007), a vision for the future of the coastline; design studios and theses conducted in the urban design schools, namely in the Master of Engineering, of Architecture and in the post-graduate Master of Urbanism and Strategic Planning (Tullen 2017; Aliaga, Van Daele, and Wambecq 2014; Chen Yu-Ting, Zarin Tabassum 2014), doctoral theses and articles on the role of infrastructure in the occupation of the Belgian coast (Van Acker 2010; Van Acker 2011). All of these studies build on the notion of abandoning a rigid and linear flood and tidal protection to promote a dynamic landscape between sea and land.

After establishing the research question, methodology and hypothesis, the main case study is discussed in three parts.

First, a brief historic reading of the relationship between cultural and natural forces is given, showing how cultural forces took the upperhand over time. Three time periods are illustrated by three specific developments on the Belgian coast: the time of the Cistercian dune abbey, followed by Van der Swaelmen's dune forest urbanization and concluded with the switch towards solutions of hard engineering.

The second part discusses the design exploration. It introduces the notion of transitioning from hard to soft engineering supported by three possible new holiday typologies.

Finally, the paper closes with a reflection on the outcome of the researchby-design, focussing on a paradigm shift as the main challenge for the future of the Belgian coast. 


\section{RESEARCH QUESTION}

The research goal is to explore an alternative future for the Belgian coast, based on two assumptions.

Firstly, is the notion that the current storm surge mitigation in the form of hard engineering is outdated and unfit to deal with the diverging future models of sea level rise and storm frequencies. As the previous studies mentioned in the introduction suggest, soft engineering approaches should be adopted, increasing the interface between sea and land as storm mitigation system.

Secondly, this paper acknowledges that the leisure industry has played an important role in the current static landscape organization.

The approach was to intrinsically attach these two assumptions to one another. Could the reinvention of the coastal landscape be realized by rethinking the holiday infrastructure, its position and distribution in the landscape?

\section{RESEARCH METHODOLOGY}

Research-by-design was adopted as a methodology, applied on a case study between Ostend and Blankenberge, arguably the stretch of the Belgian coast where the linear relationship along the coast was first implemented (Van Acker, 2010; Van Acker, 2011). The investigation uses design exploration to ignite a reflection and a framework for discussion concerning the future of the Belgian coast and the drivers to achieve it. To concretize the quality of an alternative leisure economy, the holiday typologies were explored up to an architectural scale. This scale of research-by-design was an intentional choice to not just rethink the Belgian coast as a new dynamic landscape through soft engineering, but also to critically evaluate the architectural quality (or lack thereof) of the current holiday infrastructure.

\section{RESEARCH HYPOTHESIS}

The basis for the design scenario developed by the Research Unit for Urbanism and Architecture (RUA, KU Leuven) lies in the endless landscape alterations induced by both natural and cultural forces over time, but always balancing out both. Every urban intervention was a landscape intervention at the same time. The abbey was surrounded by a protective forest, and the canal was a tree-lined dyke. Building houses meant building a forest, a dune, a dyke and other types of landscape. At some point in time, these fundamental principles of urban interaction with the landscape were lost. Most holiday houses at the coast - from containers to sunparks - are generic and reproducible cubes that do not contribute to the landscape quality. They simply take up space. A paradigm shift creeped into the urban development of the Belgian coast. From the production of landscape, urban 
development slipped into a pure consumption of landscape, and currently, a state of landscape destruction through space consumption. In addition, photographic essays and analyses made by a master thesis student on the holiday allotments in the case study, revealed their poor architectural quality (Tullen, 2017).

What if we remove and replace the generic, low-quality holiday houses with a more qualitative holiday infrastructure? Often, their quality is so poor that their removal should be easily negotiable. The holiday houses are outdated, have short lifecycles and recycling is therefore not a good idea. In addition, there is a general understanding that the added value of mass consumption of land(scape) is negative. The notion of upcycling seems more suitable: improving their intrinsic qualities by inserting them into the different (landscape and other) lifecycles of the territory. Climate change predictions are turning intervention into these areas not a matter of option, but of necessity.

\section{CASE STUDY: FROM OSTEND TO BLANKENBERGE}

\section{Historic Background}

Belgium's coastal area was a harsh landscape. The low-lying, constantly flooding areas were unsuited for permanent inhabitation. Its conquest was possible through relentless efforts of trial and error and finally, through technological advancements. The demographic explosion demanded the search for new land for agriculture and settlement. Living with travelling dunes and dispersing water, both highly dynamic, due to the brute wind and sea forces, meant that the permanent occupation of this landscape was going to be a continuous battle.

The Cistercian Dune Abbey (Leroux-Dhuys et al., 1999)

The first settlements at the coast were punctual. The Cistercian "Dune Abbey" (Abdij Ten Duinen) was one of the first to settle, around the eleventh century. The least inhospitable places were often the ideal grounds for the "ora et labora" ("pray and work") Benedictine motto: mostly forests, in this case dunes and polder landscape. The landscape was otherwise the perfect setting for their endured work ethics. The rough lands were cultivated, forests turned into farmland, dunes turned into forests and flood plains drained for all sorts of purposes. The Cistercian abbey embraced the forces of nature as tools of reflection and constructed its surrounding landscape by working with them.

Throughout the centuries, the coastal landscape changed significantly. The first set of dykes ran perpendicular to the coastline, following the main river courses into the North Sea. The dykes do not face the major confrontation line between sea and land, but are positioned there were the sea forces are already reduced by the encounter with land. 
Windmill systems, as the mill at the dune abbey, pumped the water into drainage canals. The polders were shaped in this era. In addition to the water management, there were peat excavation pits, a primary energy source in the early Middle Ages. A threefold topographical movement of the soil reshaped the coast: relatively stable sand banks in the polders and at the coast remained, although still volatile under the influence of the prevailing winds; clay lands subsided due to water table changes; and peat pits led to ponds and lakes (Fig. 1) (Ameryckx, 1959). These changes inevitably turned the coastal area into a permanently managed landscape.

1. MID-HOLOCENE SEA DEPOSITS (UNTIL 5000 BCE)

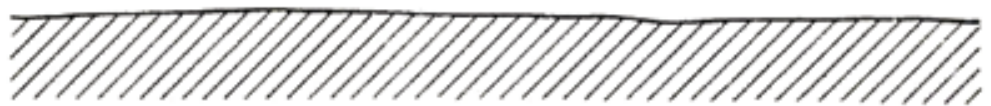

2. FORMATION OF SURFACE PEAT (5000 BCE - 300 CE)

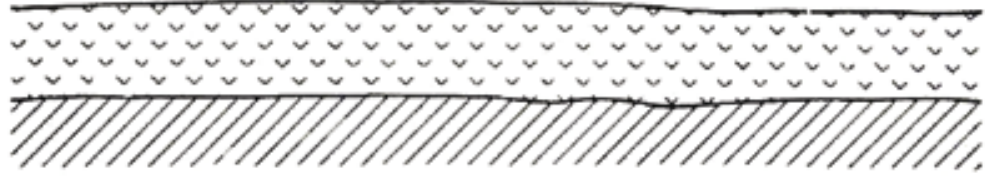

3. EROSION OF THE PEAT LANDSCAPE FOLLOWED BY MARINE SEDIMENTATION (300 CE - 900 CE)

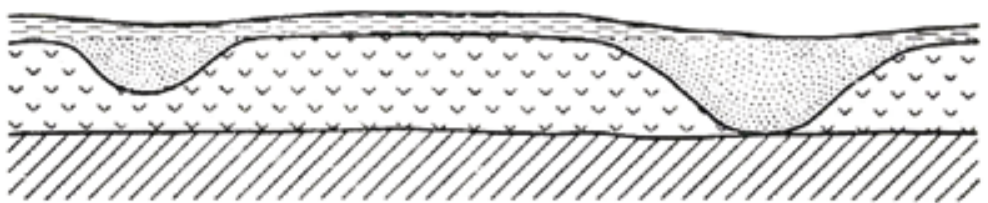

4. INVERSION OF THE TOPOGRAPHY (CURRENT SITUATION)

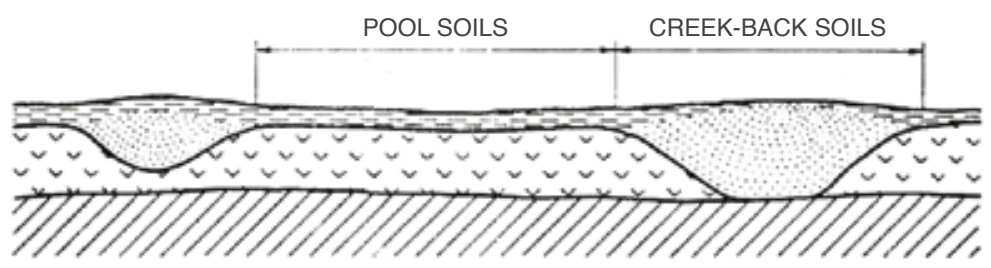

ATLANTIC SWAMP SEDIMENTS
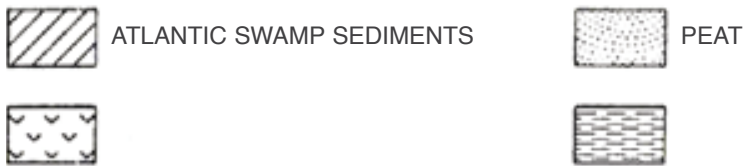

Figure 1. Sequence of soil changes in the Belgian polder landscape: in the last phase, clay subsided as sandy soil remained stable, creating the current micro topography within the polders. 


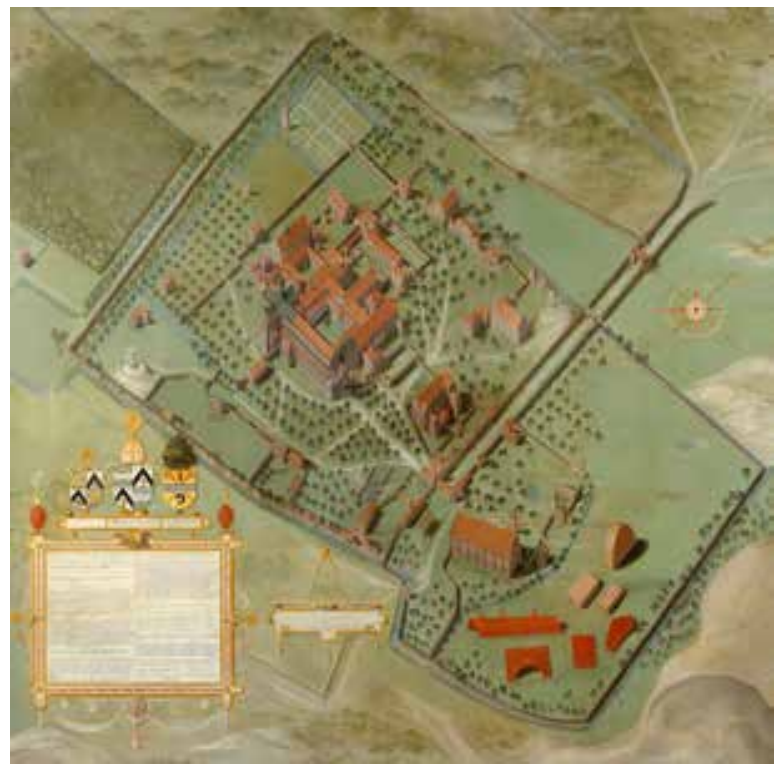

Figure 2. Axonometric plan of the abbey Ten Duinen in Koksijde, dated 1580, made by Pieter Pourbus, currently hanging in the Groeningemuseum in Bruges. The image shows the different landscapes of the dune abbey: the dunes, the water canals and the forests.

The dune abbey became an integral part of the coastal dynamic, securing the dunes by productive afforestation and pumping water into protective and extractive drainage canals. Its physical structure was completely based on these landscape logics (Fig. 2).

Van Der Swaelmen's Dune Forest (Van Der Swaelmen, 1888)

During the Industrial Revolution, the mindset towards nature shifted towards a place to be and not just a source of exploitation. During this period, the notion that city and landscape were incompatible grew (Tritsman 2016). The suffocating effects of the industry made the unspoiled nature appear attractive as a place to escape to. On the coast, this coincided with the royal wish to establish a thriving sea front, able to receive the bourgeoisie and aspiring to a life of splendor.

In 1888, the landscape architect Louis Van der Swaelmen was commissioned a prestige project for the Belgian coast. For some years, the state had envisioned a linear forested dune park that would stabilize the drifting sand and allow for strolls between Ostend and Blankenberge. A thorough study was made to prepare the planting works, taking into account previously realized and successful dune plantations as in The Hague, in The Netherlands (Fig. 3). The linear forest became a park, the National Coast Boulevard was constructed in the back and quickly the urbanization scheme for the cottage holiday houses in Le Coq came to life. Van der Swaelmen's scheme already showed the basic concepts of the forest urbanization. His proposal can be considered as an integrated plan of tidal mitigation, afforestation, and leisure infrastructure, or otherwise 


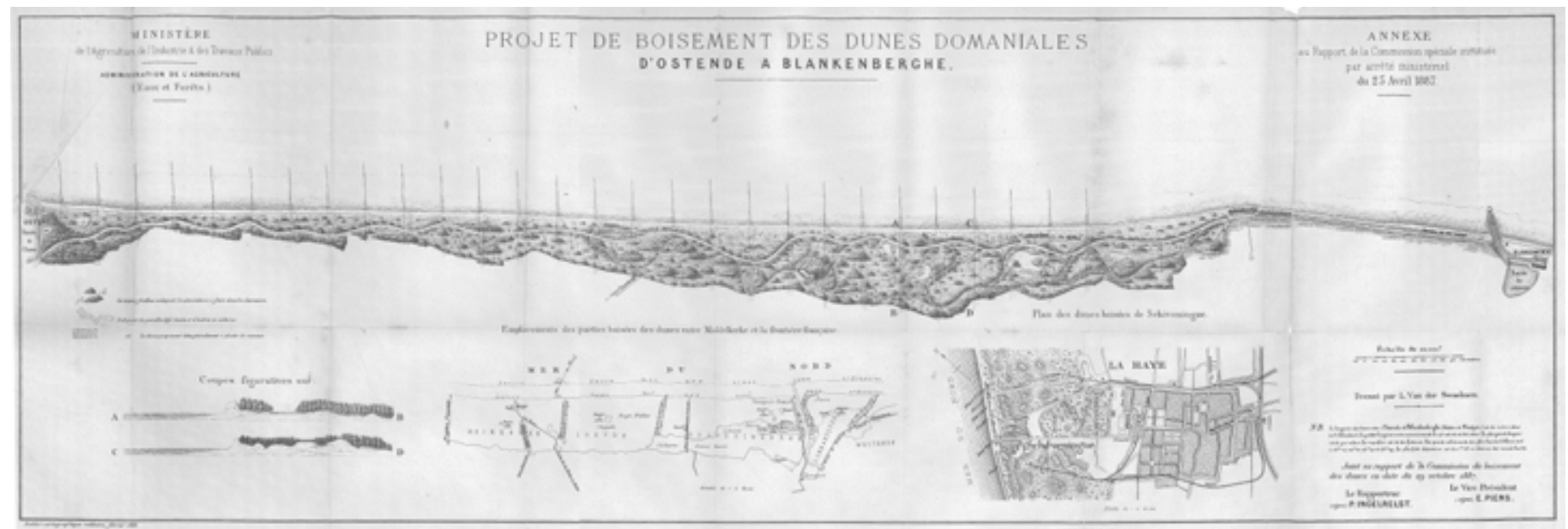

Figure 3. The detailed plan for the linear dune forest park connecting Ostend and Blankenberge, by Louis Van der Swaelmen in 1888.

said: the interweaving of urban and landscape dynamics in order to create a coherent mode of living. The transition between sea and land was constructed both as natural and as cultural landscape, starting from a system of dykes that ran perpendicularly to the coast to absorb the already diminished sea forces, towards a wide dune forest system following the coastline.

\section{The Dune becomes Dyke City}

Van der Swaelmen's dune forest was one of the few landscape urbanism interventions on the coast. Most commonly, the typical technocratic solutions of hard engineering were applied with a continuous protective dyke. It runs through most parts of the Belgian coast with some landscape interruptions where the dune systems do subsist. Both systems run intertwined and reflect the sequence of urban forms: dense settlements that turn into disperse holiday allotments. These gradually overtake the dune and polder interruptions. The seaside of the dyke is well maintained with breakwaters and long, extensive beaches (an intense dredging and sand refilling maintains them stable). On the landside, where normally one would enter the dune, the typical post-war apartment buildings arose and created the well-known Belgian coastal wall.

In between the villages, the Royal Avenue runs all along the $60 \mathrm{~km}$ [37 mi.] coastline with a fast train that connects the complete Belgian coast from west to east, from De Panne to Knokke. Along this line, on the dunes and extending into the polders, holiday houses proliferate. Its relative proximity to the beach makes its quality as an urban tissue irrelevant, resulting in generic neighborhoods with no identity (Fig. 4). The coastal landscape is absent in the way the urban fabric is organized, and the open space is dominated by concrete surfaces and caravan parking places. The holiday house allotment's mediocre building quality, its degradation and short 
lifecycle seem to be its main qualities. It all leads to the conclusion that the holiday allotment is relatively easy to remove, opening up options for the landscape to recover.

\section{Design Exploration}

\section{From Hard to Soft Engineering}

Nevertheless, there is no reason to consider this strategy the end of the holiday houses on the coast. On the contrary, the reinvention of the landscape goes hand in hand with the re-conception of the holiday houses. Urban development and landscape dynamics join forces. The holiday culture should evolve towards a more intensive, collective and qualitative occupation (and value), rather focusing on value creation than value consumption.

The removal of the low-quality leisure infrastructure allows for the change of the coastal design conception. The current system enhances linearity
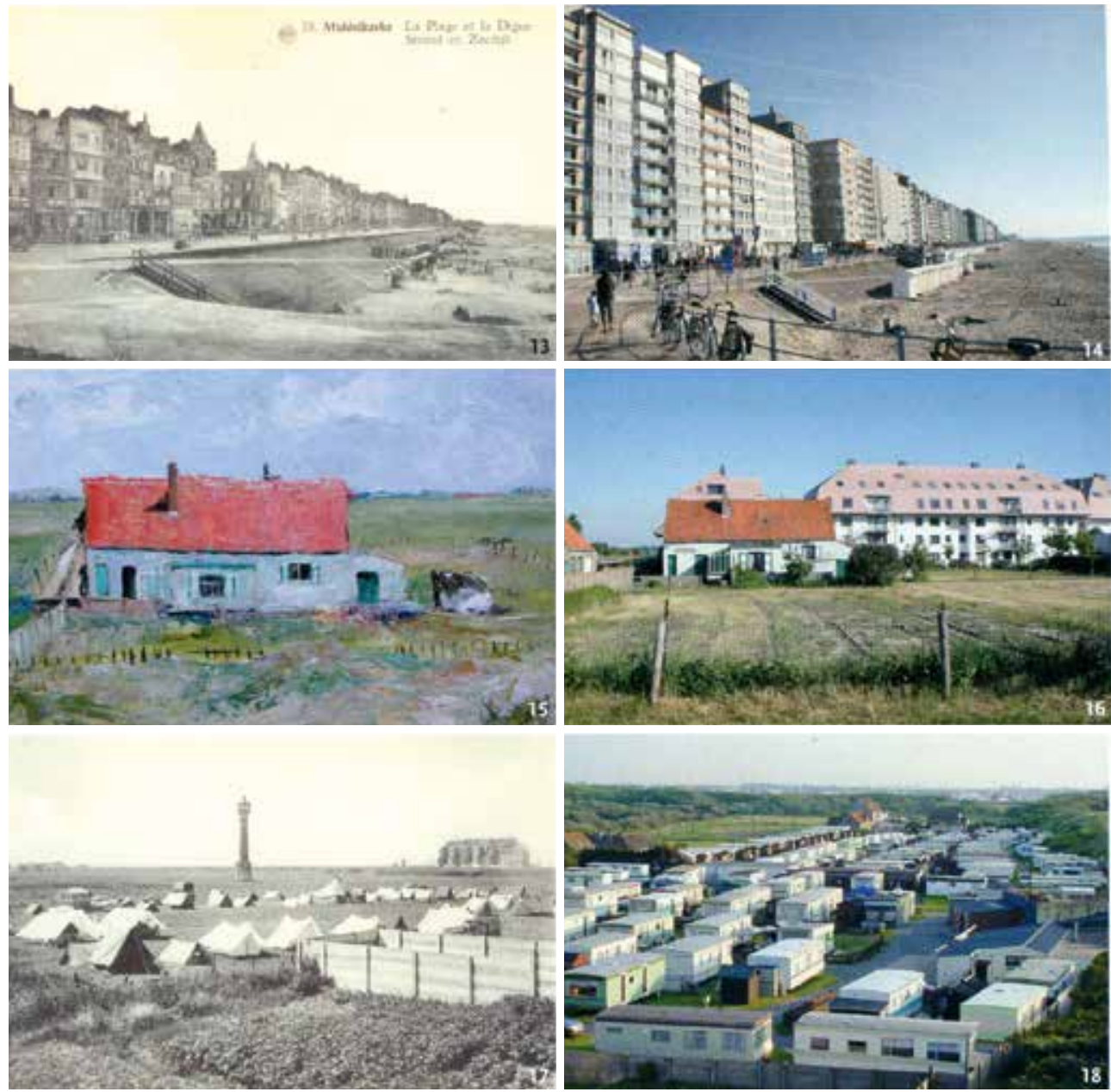

Figure 4. The "thickened" Belgian coast. A first layer of holiday houses at the coast was decontextualized by the large building operation that were realized in the back. 
repeatedly. The dyke leads to a monotonous beach, a monotonous urbanization, a monotonous seascape, etc. The iconic place where land ends and sea begins is reduced to a singular thick line (Fig. 5). In the face of climate change and the need for reconsidering management systems, the current system is exhausted. The removal of the holiday houses and the breaking of the dyke will allow the sea to invade the polders again. From a short and simplified interface between land and sea, the contact edge between land and sea is extended over a vast area.

The polders become a tidal landscape with varying height and soil characteristics; the sand dunes remain dry highlands that withstand the

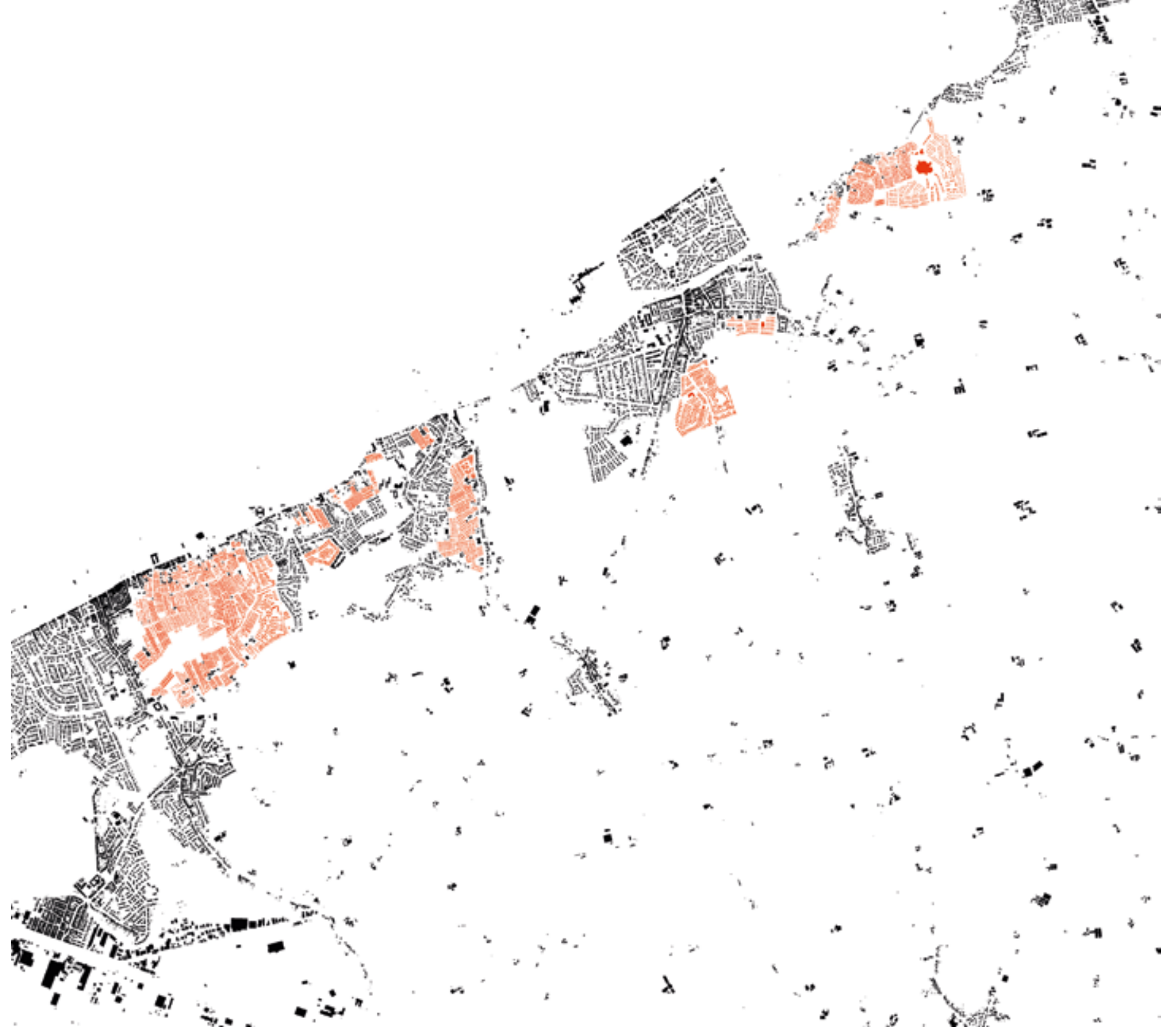

Figure 5. The urbanization between Ostend and Blankenberge. In black, the established urban tissue. In red, the low quality holiday house allotments. Their removal might be an opportunity to rethink the sea's dynamic forces. 
sea forces; the attention does not only go landwards, but also seawards by extending a pier into the sea, seeking the ultimate refuge of land in the sea. The exchange between land and sea is stretched out between them (Fig. 6). The transformation of the polders into a tidal landscape is not evident. Its low topography means it will flood almost completely on a daily basis. Only cultural islands (higher lying farms) and dune extensions will be able to keep afloat in the new sea invasion. The existing dyke system land inwards ensures that the sea is still controlled up to a safe point. Unlike the current dyke system, the existing dykes in the back of the polders can be relatively simple and low-maintenance. The long flood scape will absorb the sea forces, reducing the dependency of hard engineering solutions.

The transformation from a line to a tidal zone will significantly increase the coast's resilience against extraordinary storms, as wave impacts are absorbed by the landscape's surface resistance, augmented by the

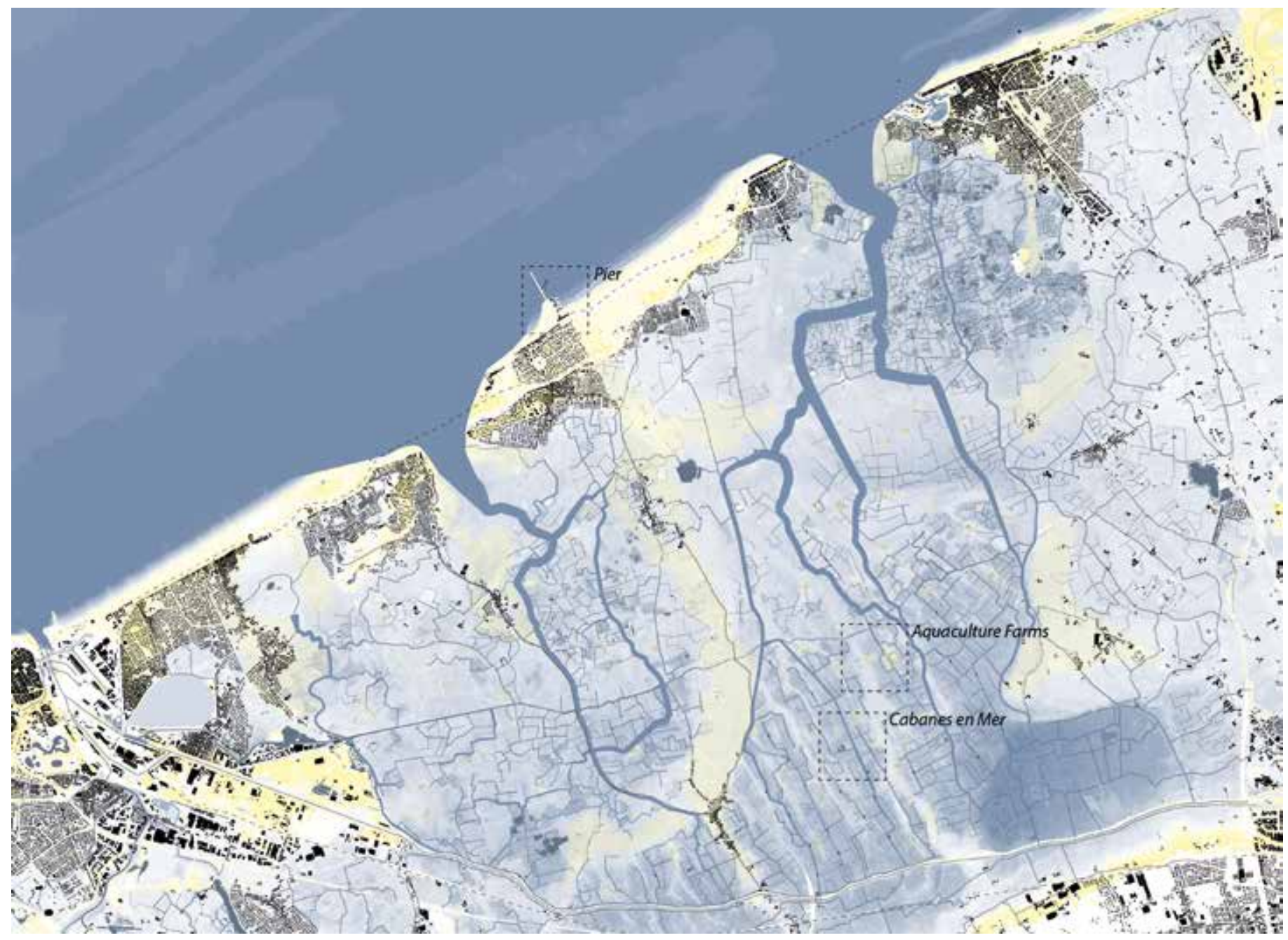

Figure 6. The new situation after opening the dykes at the points where low quality holiday houses are removed. The seawater reconquers the polder and turns it from a relatively low grassland area into a tidal landscape. On the map, the three new holiday collectives (mixed holiday house typologies) are indicated: cabanes en lagune, Aquaculture Farms and Pier. 
endless network of meandering tributaries (creeks) constantly eroding and depositing clay and sand particles. As an added value, the sea-land contact and overlap is multiplied.

Landscape Articulation: Soil with a Dash of Salt

Hard Engineering solutions aim to annihilate any sea intrusion to consolidate the urban, yet the dyke has not always resulted in a more established or qualitative urban space and, as it becomes apparent now, does not even annihilate the threat of the sea. The tidal landscape is expected to allow for a better, more resilient and qualitative urban space. The sea would no longer bounce of the main dyke, but would infiltrate in a multitude of smaller creeks. The sea could then meander through the variety of soil types, topographic locations, depressions and existing farms and infrastructure, providing equally diverse opportunities for a new and diverse economy. A wide-spread tidal landscape - sometimes sea, sometimes land - would allow for new economies of production and leisure.

The proposed transformation into a tidal landscape is based on landscape fundamentals as soil and topography. Low-lying clayish soils are frequently flooded and become tidal marshes. Sometimes they even become permanently flooded. The higher sand banks in the polder remain above high tide. More often, the existing farms lie on these sand banks and become safe-havens in the landscape. They will become part of the infrastructure of the new tidal landscape. Vice versa, the introduction of a new extensive breakwater (half pier, half breakwater) into the sea, in the continuation of "Le Coq-sur-Mer," allows the land to grow seawards. Partially, the land will grow under the influence of sedimentation, later fixed by extending the dune forests along the coast. Further into the sea the breakwater turns into a large pier that extends almost endlessly into the sea (Tullen 2017). Living here is defying the sea.

\section{Leisure Economy Reinvented}

The holiday house allows people to relax and regain peace of mind. This is mostly achieved by reconnecting humans to their basis of existence: nature. The current state of the holiday houses cannot be our collective representation of reconnecting to nature. The densely compressed matchbox houses can hardly be considered our collective shelter from where to explore nature. The shelters are not inside nature. One cannot even see nature. New shelters that live thanks to the rhythms of nature and reinforce it need to be invented. The new shelters should stimulate sustainable and thus collective use of space, resources and infrastructure. Simultaneously, these need to be diverse. The more diverse the range of holiday houses and their natural setting, the easier people will find their preferred location. 
For this piece of the Belgian coast, three holiday house typologies were developed within the thesis project by Jens Tullen (Tullen 2017), a second year graduate student in the "Master of Civil Engineering: Architecture" program. These can be considered holiday collectives since none of them are isolated, individual holiday houses. In each one of them, the individual experience is important, complemented with a sound notion of common and collective use of resources.

\section{The Cabanes en Lagune}

At the deepest point in the landscape, there are some excavated peat pits that will flood completely in case of the opening of the polders to the sea. Some of the largest water streams connect to it, turning it into an inland lagoon. Low clay soils flood daily and the watercourses are widespread. The holiday collectives cabanes en lagune (cabins in the lagoon) search disconnection from the world and its daily routines. It is obvious that these holiday cabins are on pillars, floating above the tidal landscape, connecting to the watercourses. The holiday house is a cabin. It is simple (and not pretentious). The cabin serves the landscape and only exists to provide the basic logistical support of being in a disconnected landscape. Unlike the beach cabins, they keep a safe distance. A distance of $300 \mathrm{~m}$ [984 ft.] seems to allow for an acceptable density, while cabins are practically unnoticeable between one another (Fig. 7).

The extension of the sea landscape into the polders radically changes the access to the sea from the holiday houses. They are no longer geographically restricted to the linear stretch along the royal avenue. The sea invades and requalifies the polders into a lagoon landscape with mudflats and salt marshes. The cabanes en lagune now follow the logic of the landscape instead of the logic of densification and proximity. They spread out over the tidal landscape and adopt a settlement logic that work with soil, topography and the tidal regime. Its architectural design is a continuation of the landscape dynamics; its proliferation coherent with consistent geographical features.

The sea-land interface changes completely. The road to the holiday house no longer lies through the royal avenue along the coast. The urbanization would be served by a system perpendicular to the current coastline. Villages as "Le Coq-sur-Mer," Blankenberge and other maintain their current position as extension of the land into the sea. In between them, the sea overtakes the infrastructure. As such, each village has its own path towards "the point where land turns into sea."

Although the village are often reachable by train or car through the infrastructure on dry sand banks, the cabanes en lagune are no longer reachable by train, nor car. The tidal landscape does not permit any of these modes. The main watercourses in the flood plain provide the necessary accessibility. The holiday houses are all connected by boat. 
The infrastructure is adapted to it with small piers, docking bays and special tidal entrances. The beaches lie at a small boat trip's distance. For some this will not suffice, for others this will be the perfect amount of "connected disconnection." The tidal landscape imposes its rhythms. Nature is no longer optional, but compulsory.

\section{Aquaculture Farms}

The high lying sand banks hold the farms of the former polders. They are surrounded by low-lying clayish fields and asphalt roads. The farm is turned from grassland economy into a seafood economy. The difference in topography makes a gradient of flood regimes. The lowest watercourses stay flooded. By excavating strategically, the amount of permanently flooded basins can increase. The soil extracted from these basins can be added to the sand islands and farms to expand their dry area for operational activities. The planting of trees and vegetation fixes the island and protects it from the (slow, but steady) erosive power of the sea. In between the permanently wet and dry is the flood regime. Roads and fields

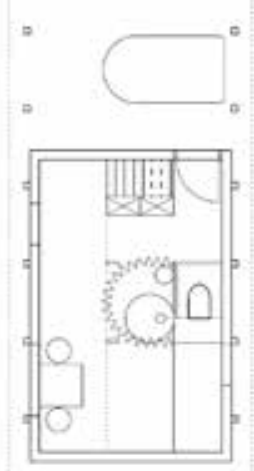

0

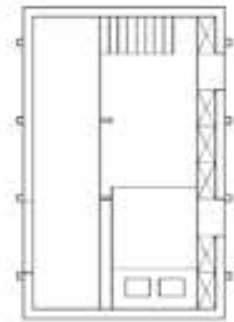

$+1$
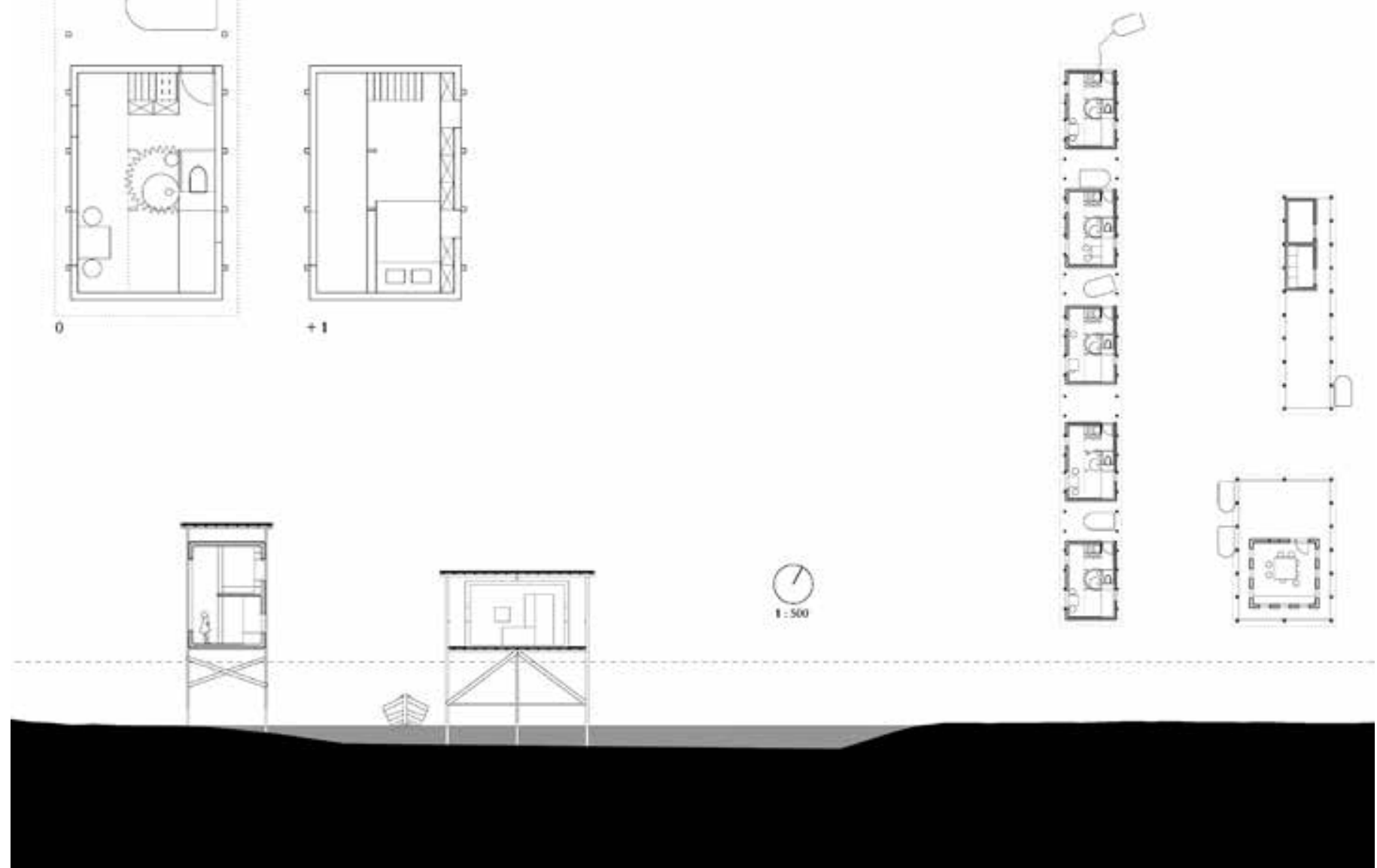

Figure 7. Floor plans and section of the cabanes en lagune. A Holiday collective designed for continuously flooded areas and river courses. Movement is only possible by boat. 
flood and dry daily. These different regimes create the perfect conditions for a sea fruit economy: shrimps are grown in nursing basin in the new farms, and then transferred to different basins; oysters are grown on a rhythmic grid of stokes; mussels can benefit from the leftovers of the landscape: asphalt roads and ruins of buildings (not saved from the new sea intrusion) can be activated to serve mussels production.

The farms thus remain the center of a (completely altered) productive landscape. On top of and next to the productive and logistical units, holiday houses can attach do this productive reality. They connect to the landscape as the production itself: some units lie close to the water and nearly flood, others lie dry and safe inside the small forests that fixes the island to the polder. The island can be considered a singular dune, the forest part of the system of dune forests that lie between sea and land. A beach naturally appears as the central connection space of the island, gliding into the surroundings. The farm adopts the structural rhythms of its productive fields, stokes, and flows into the built rhythms of the farm as retaining walls of the island (Fig. 8).

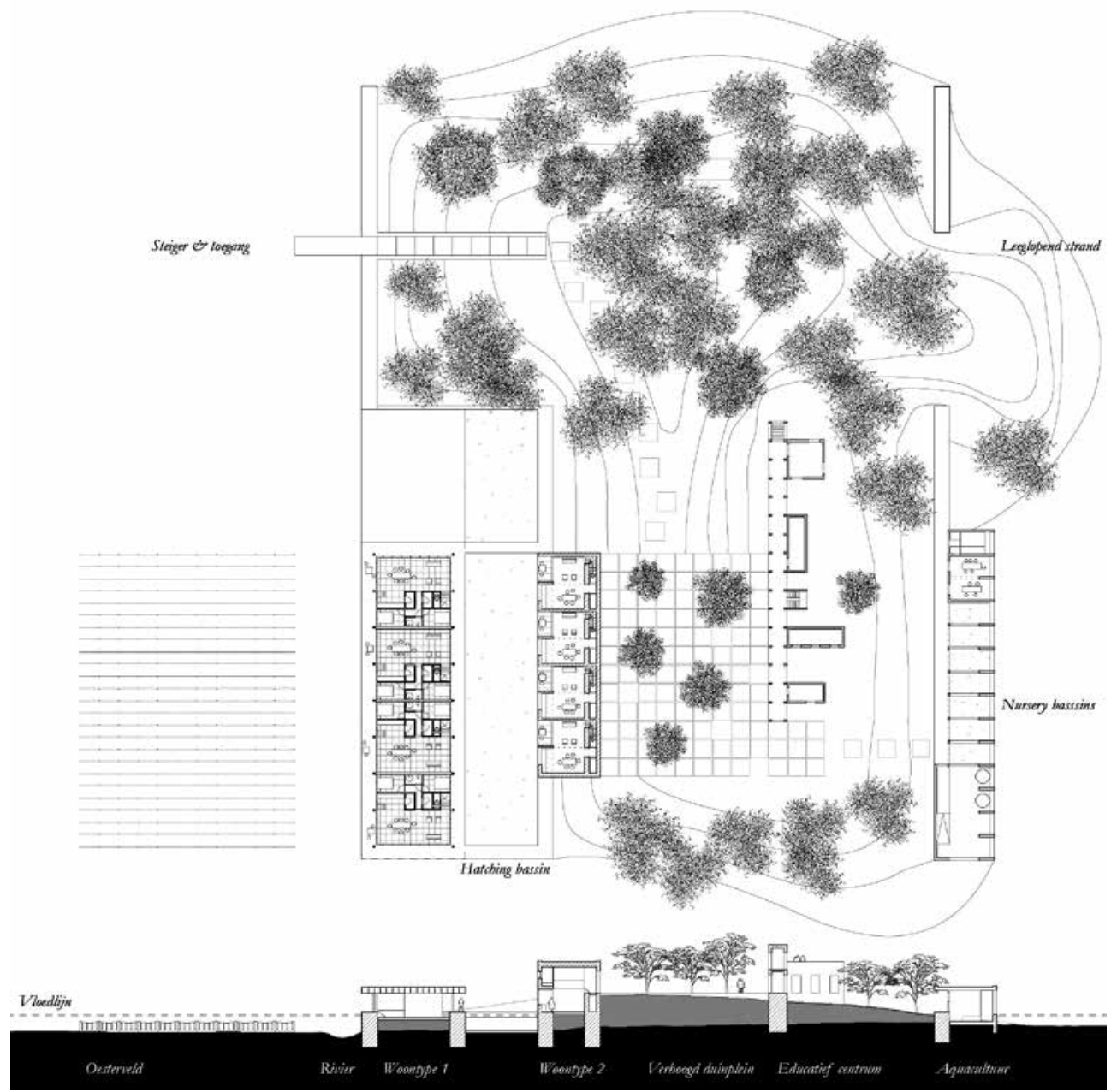

Figure 8. Organization plan of the Aquaculture farms. The holiday collective is organized around a supportive dune that flows into a productive sea fruit landscape (shrimp, oyster and mussels) that surrounds the farm. 
People searching for solitude might pass for these holiday houses.

Production is the main objective here. The farms bring enormous benefits to the tidal landscape. They introduce moments of intense production in the otherwise ecologically rich salt marshes. Therefore, the Aquaculture visitor should be well aware of the activities that happen during his stay. Fortunately, this is an open process. Visitors are invited to participate in these activities and help out with the production process, if they wish so, or retreat to the slow tidal movement of the landscape.

\section{The Pier}

As the sea moves inland, the land can also move seawards to extend the sea-land interface. A breakwater and pier extend into the sea. The natural forces of erosion and sedimentation create new land in the sea. With time, the wave breaker will create an extension of the beach with an east-west orientation - more adequate to catch sun at the beach - and the continuation of the dune and dune forest system along the "Le Coq-sur-Mer" urbanization. Where the breakwater stops, the land is reduced to the pier that extends for almost one $\mathrm{km}$ [0.6 mi.] into the sea. It gently slopes down making it disappear and reappear with the tidal movement. At the highest tide (for now), a building stands boldly in the sea (Fig. 9).

The building might seem to defy the forces of nature, yet it is completely designed to work with these forces. An underwater anchor connects to the pier. It fixes the building on the sea floor. Since most of the building stays below water for most of the time, could this be Belgium's underwater

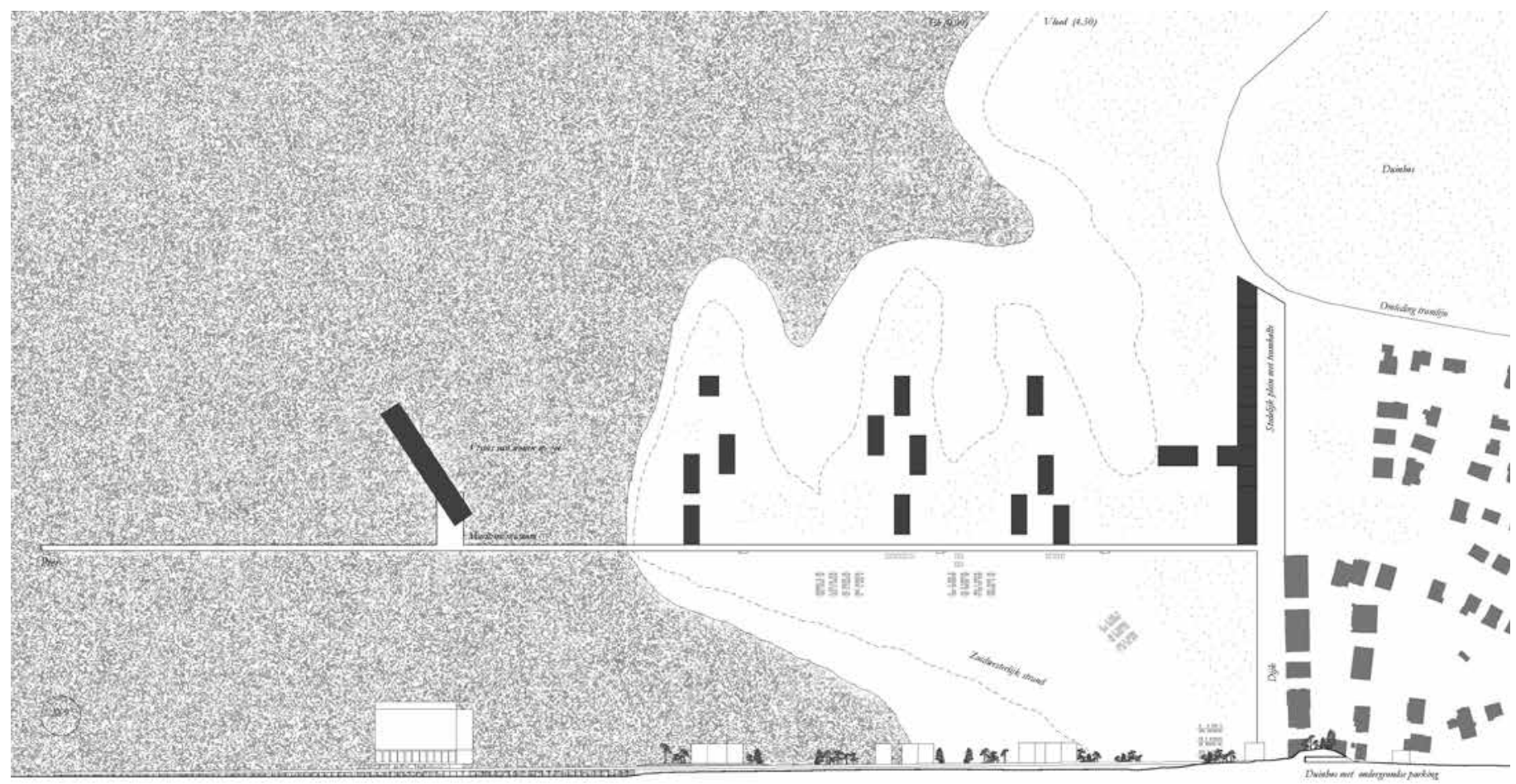

Figure 9: Intervention with the breakwater and pier. 
aquarium museum? To reduce the impact on the sea floor, there is only one more structure that carries the building. A three-level high rectangular, structural [Vierendeel] beam (vierendeelligger in Dutch) covers the span between the two supports. The beam holds typologies with view at both sides that are mainly interiorized with protected terraces that sometimes span more than one floor to experience the structural beams. Utilitarian spaces are located within the thickness of the steel structure. Since these holiday units are closer to the sea floor, the amount of salty and humid winds, or even sea water in the case of storms, is relatively high. Their exterior circulation is at the wind-protected side. The floors above are battered by the wind. The units are therefore rotated inside the building's carcass to protect visitors from the prevailing west wind. The top floors benefit from the view. The units are duplex typologies with a fantastic view on the top floor (Fig. 10).

\section{Oscillating between Land and Sea}

In contrast with the inland-lying cabanes en lagune or the Aquaculture Farms, these holiday apartments take the full force of the sea. They are completely exposed. The holiday units can no longer aspire to an extended individual space. As a compact collective, the holiday units stand ground in one of the harshest of environments. The experience is unique. Half of the experience is not being in the holiday house itself, but the trajectory and the rhythms of life that accompany a stay in the sea. The walk to the holiday house means submerging the sea. From the moment people step from the dyke onto the wave breaker, they start taking distance from the land. The forces of the sea become more and more perceivable since they are surrounding the wave breaker in a non-pretentious, transparent way: the sedimentation and erosion, the tides and the structural resistance of the wave breaker. With every step onto the pier, the safety of land is left behind. This walk can be extended indefinitely along the one-km [0.6-mi.] pier into the sea. The pier gently slopes down and literally disappears into the water. The pier holiday collective stands as a last refuge before complete disappearance into the sea.

The building itself also transpires this motion between land and sea, but as a reversed experience. Entering the building one is completely in contact with the sea and its tides. The public space partially floods and gives complete access to the sea through the aquarium museum. The first holiday houses are also relatively close to the sea. Its robust structure projects resistance to the sea's forces. The higher up, the more disconnected one gets from this sea reality. A distance is taken and other dynamics become more dominant, namely the wind. The wind is the result of the openness and exposure of the building in the vast sea, but the relationship is already slightly more indirect. Finally, on the top floors, the relationship becomes completely ambiguous. Their connection to the sea is merely abstract, being inside, yet not actually experiencing its dynamics 

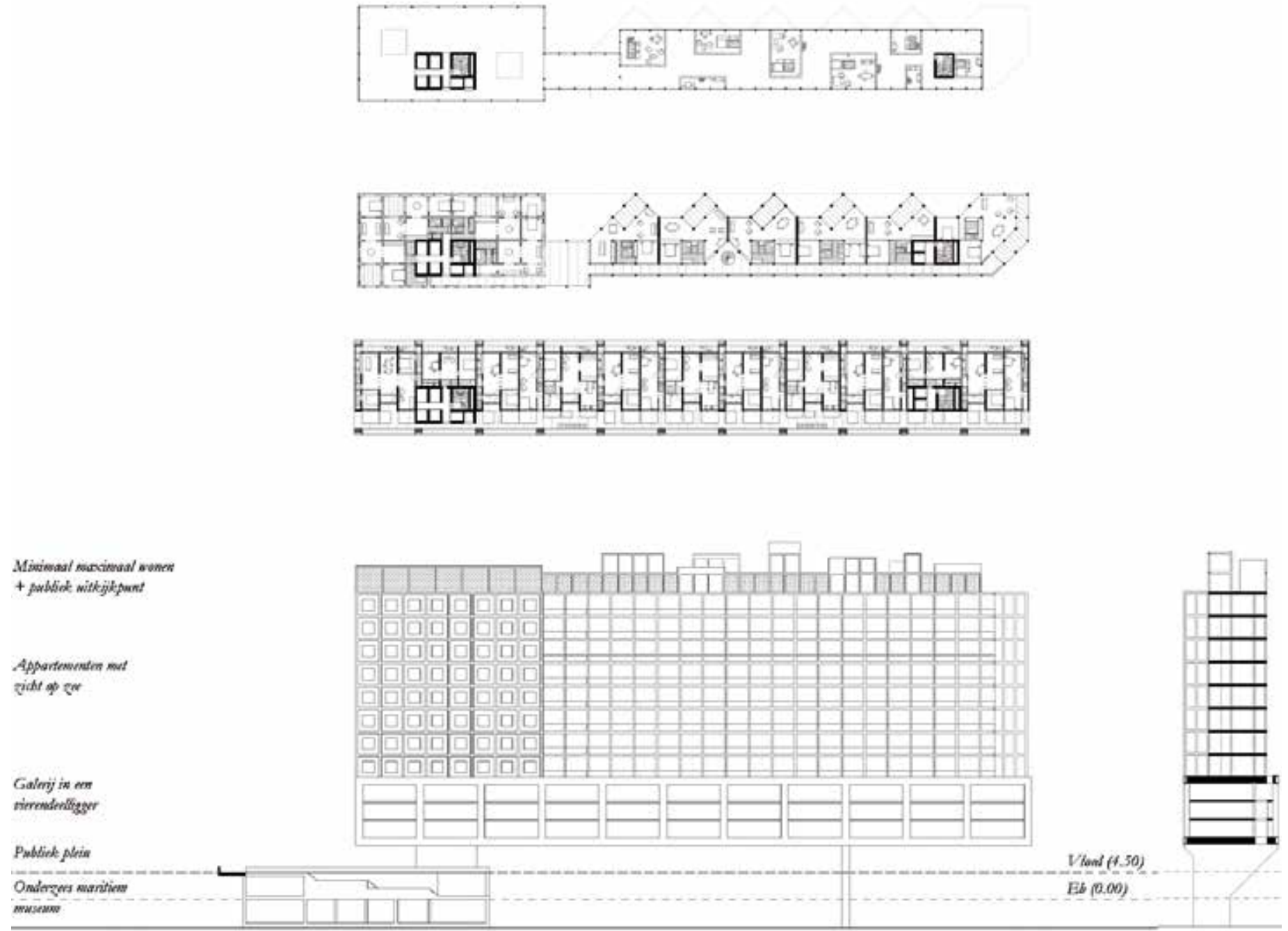

Figure 10. Plans, section and façade of the anchor refugee along the pier.

from close by. What captures one when passing through this process from land to sea, rising in the building, is finally the view on the land again. The nostalgia of where one came from, and where one is. In addition, here, the reconnection to nature as a way to disconnect from everyday routines is realized, yet the experience exists primarily on a "meta-level," where one is able to contemplate from far about the forces that guide our life.

\section{CONCLUSION}

On an analytical level, the range of holiday houses produced in this case study reveals an intrinsic pattern. Before, the holiday allotments had little or no diversity in terms of quality, location, connectivity and relation to the landscape, making their removal imminent: because of their lack of contribution to the coastal urbanization and because they impeded the landscape from functioning as a dynamic system. The breaking of the dyke has brought an incredible quality, as the soil diversity, tidal regimes, 
changing topography and landscape legacy creates endless options for a new leisure economy that can actually contribute to a varied interest of society.

In the renewed tidal landscape, the height differences are small, yet important. The expression of each holiday collective comes from its physical presence in the landscape. A section crossing the whole new tidal landscape into the sea demonstrates these gentle, important nuances.

The cabanes en lagune transpire the life of disconnected connection to the land, following the main river courses that define this connectivity and fish economy. The Aquaculture farms show the diverse productive economy of the tidal rhythm. The gradual slope of the dune island into the tidal landscape allows for a diverse sea fruit production. The higher parts of the island become dunes and productive dune forests, protecting the islands in the oscillating tidal landscape, serving as refuges for wildlife (and humans) astray. Finally, the Pier allows for sea proximity, from an intense relationship of living almost in the sea, to experiencing the sea from a distance. The Pier symbolically builds on the knowledge of the sea - the aquarium museum (Fig. 11).

This alternative future for holiday house economy reflects the essence of the research-by-design case study: breaking loose from the previously adapted paradigms that are rapidly becoming dead-end solutions to mitigate the sea forces. Hard engineering has the intrinsic default to lack dynamic response to changing conditions and uncertainties. Solutions are based on well-calculated models and supposedly reliable engineering tools, yet when either change, the readjustments are slow and costly. The soft engineering approach that was tested faces the challenges of a gigantic transformation: the readjustment of the territory from polder to tidal landscape.

Due to the large number of stakeholders, the soft engineering remains relatively utopian. Yet, once accomplished, storm and flood mitigation are predicted to be much more controllable (in space and time), as the territory will be more resilient to extreme events. It must be said that letting go of the

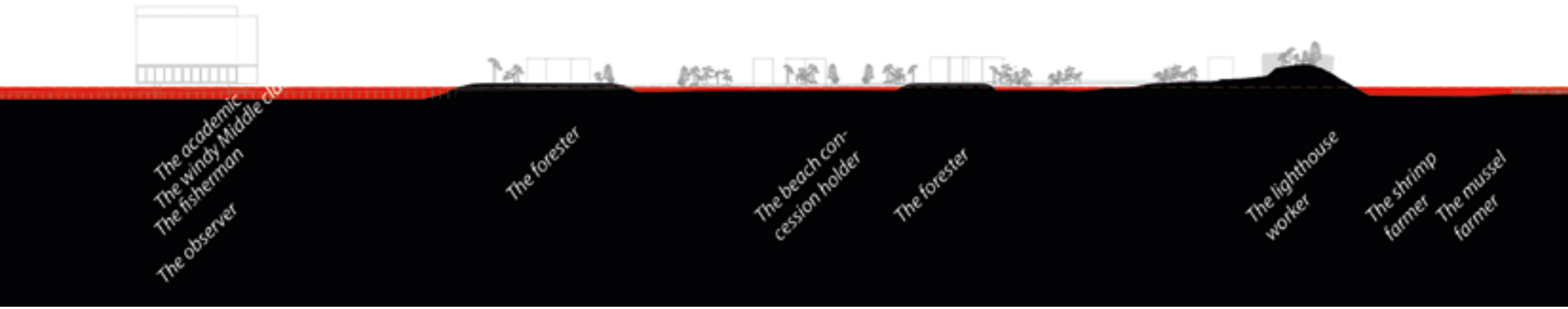

Figure 11. A representation of soil, tides and holiday collectives as intrinsically connected entities through their mutual exchange. The red highlights the high tide, showing how land and water continuously alternate throughout the whole dune and polder landscape. 
current paradigm is not a matter of choice, but a matter of necessity if we do not want to face grave calamities in the (near) future.

The biggest hurdle to overcome is the paradigm shift. The sea-land interface in Belgium is becoming more and more fixed. To design a more resilient future for this piece of the lowlands, dealing with climate change and sea level rise, the paradigm of the dyke must be given up. The research-by-design assumed that a set of interventions - breaking the dyke, fixing the dunes, eroding the creeks, creating new lagoons, extending the beach, etc. - uploads the landscape with a sequential resilience that wears down the sea forces. Flooding would become desirable (since that is what feeds the productive landscape). The final flood protection beyond the tidal landscape, already much into the interior, would reach the natural five $\mathrm{m}$ [16 ft.] height line, a significant topographic rise that marks the transition from the polder into the Flanders lowlands (with the city of Bruges at the edge in this case study).

Throughout the process, the research shows that reducing the reliance of a single defense system also means giving up our current paradigm on coastal urbanization and, by extension, on the leisure economy on the coast. From a largely linear system, the coast becomes a landscape of settlements that extend into the sea, and of retracting back into the tidal landscape. The historic villages form a set of "end-of-the-line" settlements at the sea, while a landscape in the back open up for alternative living conditions, illustrated by some of the new holiday typologies. The notion of flooding, one of the most prominent concerns when discussing the sea level rise and storm frequency, is simply sidelined because instead of having the urban realm occupy and consume land unfit for urbanization, the urban now seeks the qualities of the landscape and abides by it. Flooding is interpreted as the natural phenomenon of tidal landscape and thus needs no mitigation. The "problem" simply becomes sidelined.

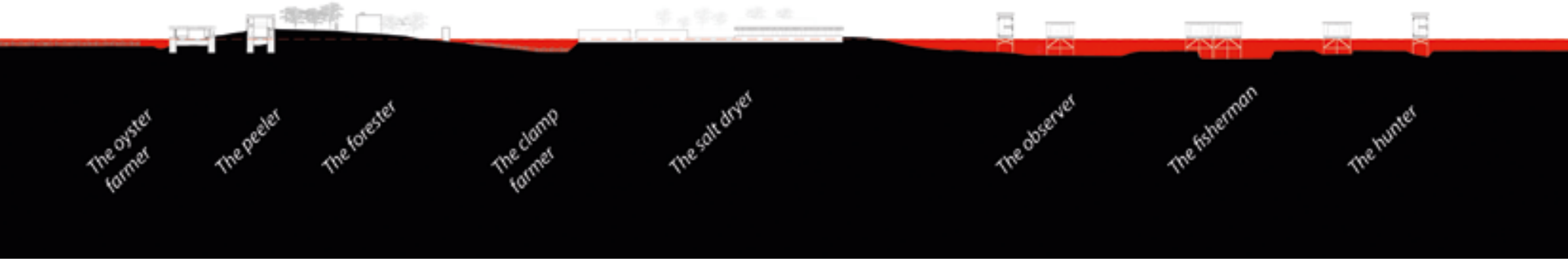




\section{References}

Aliaga, Victor Manuel, Erik Van Daele, and Wim Wambecq. "Recovering Dynamic Landscapes along the Belgian Coast." Leuven, Belg.: Katholieke Universiteit Leuven (KUL), Faculty of Engineering, 2014.

Ameryckx, J. De ontstaansgeschiedenis van de zeepolders. Edited by Centrum voor Bodemkartering IWONL. Brussel: Centrum voor Bodemkartering IWONL, 1959.

Beyaert, Marc, Marc Antrop, Philippe De Maeyer, Christian Vandermotten, Claire Billen, Jean-Michel Decroly, Claire Neuray, Thérèse Ongena, Stéphanie Queriat, Isabelle Van den Steen, and Benjamin Wayens. België in kaart: de evolutie van het landschap in drie eeuwen cartografie. Edited by Brussel Nationaal Geografisch Instituut. Tielt, Belg.: Tielt Lannoo, 2006.

Chen, Y.-T. Recovering the Dynamism of the Belgian Coast: a Landscape Urbanism Approach on Infrastructure and Urbanization. Leuven, Belg.: KUL, Faculty of Engineering, 2014.

Cornilly, Jeroen. Modern bouwen tussen strand en duin: bouwen aan de Belgische kust in de periode 1945-1975. Bruges: Provincie West-Vlaanderen, 2007.

Janssens, Nel, and Charlotte Geldof. "The Future Commons 2070: the Ethical Problem of the Territorialization of the North Sea." 50th ISOCARP Congress, Gdynia, Poland, 2014.

Leroux-Dhuys, Jean-François, and Henri Gaud. Cisterciënzer abdijen: geschiedenis en architectuur. Cologne, Ger.: Könemann, 1999.

Tabassum, Zarin, Erik Van Daele, and Wim Wambecq. "Redynamising the Recreational Urban Forest Landscape in Belgian Coast. Case Area: Bredene.” Leuven, Belg.: KUL, Faculty of Engineering, 2014.

Tritsmans, Bart. 'Bomen zijn waardevolle bijkomstigheden'stedelijk groen in Antwerpen, 1859-1973. Leuven, Belg.: Universitaire Pers Leuven, 2016.

Tullen, Jens. "Re-Dynamizing the Belgian Coast. A Case Study between Ostend and Blankenberge." Leuven, Belg.: KUL, Department of Architecture, 2017.

Van der Swaelmen, Louis. Le boisement du littoral maritime belge. Edited by Louis Van der Swaelmen. Bruxelles: Muquardt, 1888.

Van Acker, M. "De tram maakte van de kust een vastgoedeldorado." Ruimte: vakblad van de Vlaamse Vereniging voor Ruimte en Planning 2 (2010): 74-81.

- - . From Flux to Frame: the Infrastructure Project as a Vehicle of Territorial Imagination and an Instrument of Urbanization in Belgium since the Early 19th Century. Leuven, Belg.: KUL, Faculteit Ingenieurswetenschappen, 2011.

Vlaams Architectuurinstituut, Vocatio, VO kunst en erfgoed, with Belgische Stichting de Roeping, Plandag 2009. "The Future Commons 2070." Map C01: Harwich to Hoek van Holland and Dover Strait [1:200.000]. S.I.: Magnificent surroundings, 2011. 


\section{Acknowledgments}

This essay is based on knowledge produced through research-by-design elaborated on two different occasions: one being an urban design studio from a Master of Urbanism and Strategic Planning program and post-graduate Master in Urbanism theses (Chen, 2014, Aliaga et al., 2014, Tabassum et al., 2014), in the spring of 2014; the other being an architecture master thesis in the academic year 2016-17 (Tullen, 2017). Both researches explored an alternative future for the Belgian coast through design.

\section{Credits}

Figure 1: retrieved from Ameryckx, 1959: 19.

Figure 2: retrieved from Lukas I Art in Flanders, photo by Hugo Maertens.

Figure 3: retrieved from Van der Swaelmen, 1888.

Figure 4: retrieved from Beyaert, et al. 2006: 215 .

Figure 5: retrieved from Tullen, 2017: 81.

Figure 6: retrieved from Tullen, 2017: 136, 137.

Figure 7: retrieved from Tullen, 2017: 170-171.

Figure 8: retrieved from Tullen, 2017: 163.

Figure 9: retrieved from Tullen, 2017: 144-145.

Figure 10: retrieved from Tullen, 2017: 146-149.

Figure 11: drawing produced by the Author, based on Tullen, 2017.

Wim Wambecq is an architect and urban designer. He holds degrees from KU-Leuven (Belgium), IUAV-Venice (Italy), TU-Delft (The Netherlands) and UPC-Barcelona. After a few years in practice with Studio Associato Bernardo Secchi - Paola Viganò of urbanism and architecture in Brussels and Milan, he began working on a doctoral dissertation investigating the interplay between urbanism and forestry in the Flemish nebulous city. He is also active in design studios on landscape urbanism on East- and South-African development contexts. E-mail:wim.wambecq@kuleuven.be

Bruno De Meulder studied architecture at the KULeuven, where he also developed a doctoral dissertation on urbanism in the Belgian Congo. He currently teaches urbanism at the KU-Leuven, where he is the Director of the post-graduate programs on human settlements and urbanism. In his research is at the intersection between theory and practice, analysis and design, history and contemporary urban practices.

E-mail: bruno.demeulder@kuleuven.be 